\title{
Profile of adalimumab and its potential in the treatment of uveitis
}

\author{
This article was published in the following Dove Press journal: \\ Drug Design, Development and Therapy \\ 19 September 2016 \\ Number of times this article has been viewed
}

\author{
Stephen J Balevic \\ C Egla Rabinovich \\ Department of Pediatric \\ Rheumatology, Duke University \\ Medical Center, Durham, NC, USA
}

Correspondence: C Egla Rabinovich

Department of Pediatric Rheumatology,

Duke University Medical Center, 230 I

Erwin Road, CHC, T-level, Durham,

NC 277I0, USA

$\mathrm{Tel}+\mathrm{I} 9196844291$

Fax +19196846616

Email egla.rabinovich@duke.edu

\begin{abstract}
Uveitis refers to the presence of intraocular inflammation, and as a strict definition compromises the iris and ciliary body anteriorly and the choroid posteriorly (the uvea). Untreated, uveitis can lead to visual loss or blindness. The etiology of uveitis can include both infectious and noninfectious (usually immune-mediated) causes, the latter of which are often mediated predominantly by Th1 $\mathrm{CD} 4^{+} \mathrm{T}$-cells that secrete proinflammatory cytokines. Tumor necrosis factor-alpha $(\mathrm{TNF}-\alpha)$ is a proinflammatory cytokine involved in the pathogenesis of uveitis, which at high concentrations can cause excess inflammation and tissue damage. Adalimumab is a recombinant human IgG1 monoclonal antibody specific for human TNF- $\alpha$. Historically, corticosteroids and methotrexate were used to treat uveitis; however, newer biologic agents such as adalimumab have revolutionized therapy for noninfectious uveitis. Adalimumab has shown efficacy in treating refractory uveitis in multiple settings, including idiopathic disease, juvenile idiopathic arthritis, sarcoidosis, Behçets disease, and uveitis secondary to spondyloarthropathies, among several other noninfectious uveitis conditions. In this paper, we will review the profile of adalimumab, the role of TNF- $\alpha$ in uveitis, discuss safety data, and summarize key articles evaluating the efficacy of adalimumab in treating uveitis secondary to the most commonly associated autoimmune diseases.
\end{abstract}

Keywords: uveitis, autoimmune disease, adalimumab, TNF- $\alpha$

\section{Introduction}

Uveitis refers to the presence of intraocular inflammation, and as a strict definition compromises the iris and ciliary body anteriorly and the choroid posteriorly (the uvea). ${ }^{1}$ The most feared complication of uveitis is visual loss, and in severe cases, blindness. Historically, corticosteroids and methotrexate were used to treat uveitis; however, newer biologic agents such as adalimumab have revolutionized therapy for noninfectious uveitis. In this paper, we will review the profile of adalimumab, the role of tumor necrosis factor-alpha (TNF- $\alpha$ ) in uveitis, and summarize key articles evaluating the efficacy and safety of adalimumab in treating uveitis secondary to the most commonly associated autoimmune diseases.

\section{Uveitis}

Due to the heterogeneity in terminology used to describe uveitis, as well as differences in grading anterior chamber cells, anterior chamber flare, and definitions of disease activity, the Standardization of Uveitis Nomenclature (SUN) Working Group has proposed helpful terminology for classifying uveitis and grading the number of anterior chamber cells and flare. ${ }^{2}$ The SUN classification suggests using an anatomic classification based on the site of inflammation, and this classification will be used in this review (Table 1). The SUN criteria also further classify uveitis based on the hereby accept the Terms. Non-commercial uses of the work are permitted without any furcther permission from Dove Medical Press Limited, provided the work is properly attributed. For permission for commercial use of this work, please see paragraphs 4.2 and 5 of our Terms (https://www.dovepress.com/terms.php). 
Table I The SUN Working Group classification of uveitis

\begin{tabular}{llll}
\hline & Anterior uveitis & Intermediate uveitis & Posterior uveitis \\
\hline $\begin{array}{l}\text { Primary site of } \\
\text { inflammation }\end{array}$ & Anterior chamber & Vitreous & Retina or choroid \\
$\begin{array}{l}\text { Included } \\
\text { nomenclature }\end{array}$ & $\begin{array}{l}\text { Iritis, iridocyclitis, } \\
\text { anterior cyclitis }\end{array}$ & $\begin{array}{l}\text { Pars planitis, posterior } \\
\text { cyclitis, hyalitis }\end{array}$ & $\begin{array}{l}\text { Focal, multifocal, or diffuse choroiditis, } \\
\text { chorioretinitis, retinochoroiditis, } \\
\text { retinitis, neuroretinitis }\end{array}$ \\
\hline
\end{tabular}

Note: Adapted from Am J Ophthalmol, I 40/3, Jabs DA, Nussenblatt RB, Rosenbaum JT; Standardization of Uveitis Nomenclature Working Group, Standardization of uveitis nomenclature for reporting clinical data. Results of the First International Workshop, 509-516, ${ }^{2}$ Copyright 2005, with permission from Elsevier.

Abbreviation: SUN, Standardization of Uveitis Nomenclature.

onset (sudden or insidious), duration (limited or persistent), and course (acute, recurrent, or chronic).

The etiology of uveitis can include both infectious and noninfectious (usually immune-mediated) causes. When caused by autoimmune disease, chemical mediators may result in vascular dilation, increased vascular permeability, and infiltration of cells in the eye; respectively, this corresponds to conjunctival injection, aqueous flare, and visible inflammatory cells in the eye. ${ }^{3}$ The most common immunemediated causes of uveitis that can be treated with adalimumab include juvenile idiopathic arthritis (JIA), sarcoidosis, Behçets disease, inflammatory bowel disease, and the spondyloarthropathies (often associated with human leukocyte antigen-B27), as well as noninfectious idiopathic uveitis. Less commonly, adalimumab has been used in the treatment of other rare diseases, such as Vogt-Koyanagi-Harada disease. The prevalence of associated systemic disease varies widely depending on age group, sex, and ethnicity. For example, in children, a majority (as high as $70 \%-80 \%$ in some references) of uveitis is idiopathic, with JIA being the most commonly associated systemic disease. ${ }^{1}$ This paper will not specifically focus on uveitis from infectious causes, nor other causes for which adalimumab is not routinely used (ie, systemic lupus erythematosus, multiple sclerosis, etc).

There is no standardized protocol for the treatment of noninfectious uveitis. In general, a stepwise approach is often used beginning with corticosteroids and progressing to additional immunosuppressive agents as needed. ${ }^{1}$ Commonly used nonbiologic agents include methotrexate, azathioprine, and, less commonly, mycophenolate mofetil. Even more rarely, calcineurin inhibitors and alkylating agents such as cyclophosphamide have been used. Biologic agents such as adalimumab are increasingly being used due to their efficacy and corticosteroid-sparing effect, which can reduce treatmentrelated ocular adverse events such as glaucoma and cataracts. As of June 2016, the US Food and Drug Administration (FDA) approved adalimumab as the first noncorticosteroid medication for the treatment of noninfectious intermediate, posterior, and panuveitis in adults.

\section{Pathogenesis and link with TNF- $\alpha$}

TNF- $\alpha$ is a proinflammatory cytokine that can be secreted by several different immune (most commonly macrophages and lymphocytes) and nonimmune cells, and is a key mediator of the body's normal inflammatory response to infection or tissue injury. At high concentrations, however, it can lead to excess inflammation and tissue damage. ${ }^{4}$ It has been detected in several tissues affected by active inflammation, including the synovial fluid in patients with rheumatoid arthritis (RA), as well as the gut in patients with inflammatory bowel disease and the aqueous humor in patients with uveitis. ${ }^{5}$ It exists as a homotrimer that is initially present on cell surfaces, but can be cleaved to release a soluble cytokine. ${ }^{4}$ Both membranebound and soluble TNF- $\alpha$ are biologically active and can interact with one of two receptors: TNFR1 (p55, CD120a) and TNFR2 (p75, CD120b), causing several biologic effects. ${ }^{4}$ The most pertinent downstream effect of binding to the TNF receptors includes the rapid induction of cytokines (such as interleukin [IL]-1 and IL-6) and subsequent initiation of a proinflammatory cascade that can lead to tissue damage and destruction. ${ }^{6}$

Autoimmune uveitis is mediated predominantly by Th1 $\mathrm{CD}^{+}{ }^{+} \mathrm{T}$-cells, and activated T-cells have been detected in patients with uveitis. ${ }^{7}$ Activation of these T-cells increases the production of proinflammatory cytokines such as IL-2, interferon gamma, and TNF- $\alpha$, among others. ${ }^{7}$ Studies have also shown increased levels of proinflammatory cytokines in the aqueous humor of patients with uveitis, ${ }^{8}$ and in general, there is a positive correlation between several inflammatory cytokines and cellular infiltrate in the aqueous humor. Interestingly, while one study of cytokine profiles of uveitis in humans showed low levels of TNF- $\alpha$ in uveitis, animal models have conversely showed an increase in TNF- $\alpha$ in uveitis. ${ }^{89}$ In a rabbit animal model, intravitreal injection of homologous TNF- $\alpha$ caused a rapid cellular inflammatory response and protein leakage; subsequent administration of anti-TNF- $\alpha$ reduced the number of infiltrating neutrophils by $50 \%$, mononuclear cells by $58 \%$, and protein leakage by $42 \% .{ }^{9}$ This, in combination with the data implicating 
Th1 CD4 ${ }^{+}$T-cells as the predominant mediators of disease, forms a rational basis for targeting TNF- $\alpha$ therapeutically in uveitis.

\section{Profile of adalimumab}

Adalimumab (Humira ${ }^{\circledR}$; AbbVie Inc., North Chicago, IL, USA) is a recombinant human IgG1 monoclonal antibody specific for human TNF- $\alpha$ (Figure 1). This antibody has human-derived heavy and light chain variable regions and human $\mathrm{IgG} 1 \kappa$ constant regions and is produced by recombinant DNA technology in mammalian cells. ${ }^{10}$ It consists of 1,330 amino acids and has a molecular weight of $148 \mathrm{kDa} .{ }^{10}$ Other FDA approved indications for adalimumab include treatment for RA, JIA, psoriatic arthritis, ankylosing spondylitis, adult and pediatric Crohn's disease, ulcerative colitis, plaque psoriasis, and hidradenitis suppurativa. ${ }^{10}$

Adalimumab has two predominant mechanisms of action: 1) it binds specifically to TNF- $\alpha$ and blocks its interaction with the p55 and p75 cell surface TNF receptors, and 2) it lyses cells with surface TNF in the presence of complement, although other mechanisms such as reverse signaling may contribute to cytokine suppression and initiation of apoptosis. ${ }^{4,10}$

The dosage of adalimumab varies by indication and age. In adults, the standard dosage of adalimumab is $40 \mathrm{mg}$ subcutaneous (SC) every other week for RA, psoriatic arthritis, and ankylosing spondylitis. ${ }^{10}$ For the treatment of JIA in children aged 2-17 years, the standard dosage for adalimumab ranges from $10 \mathrm{mg}$ SC every other week (10 to $<15 \mathrm{~kg}$ ) to $20 \mathrm{mg}$ every other week (15 to $<30 \mathrm{~kg}$ ) and $40 \mathrm{mg}$ every other week ( $\geq 30 \mathrm{~kg}) .{ }^{10}$ For uveitis in children aged $\geq 6$ years and adolescents, some authors have suggested a dose of $24 \mathrm{mg} / \mathrm{m}^{2}$ every 2 weeks with a maximum dose of $40 \mathrm{mg} .{ }^{11}$ Additionally, some others have used

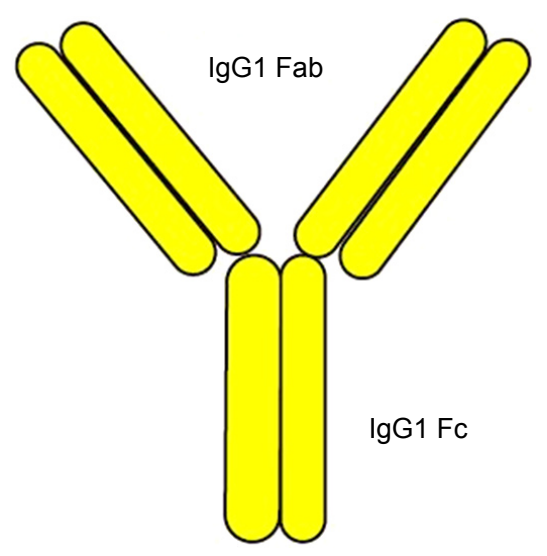

Figure I Structure of adalimumab. weekly dosage of adalimumab for pediatric uveitis. ${ }^{12}$ A recent open-label, prospective pilot study also evaluated the use of intravitreal adalimumab for noninfectious uveitis at a dose of $1.5 \mathrm{mg}$ given at weeks 0 and 2 and every 4 weeks thereafter for a total of 26 weeks, with promising results. ${ }^{13}$ When used at doses of $40 \mathrm{mg}$ SC every other week, the average concentration at steady state was about $5.5 \pm 2.5 \mathrm{mg} / \mathrm{L} .{ }^{14,15}$ The half-life of a single $40 \mathrm{mg}$ dose is approximately 14 days (range 10-20 days), and the volume of distribution is estimated to be $4.7-6.1$ L. ${ }^{14,15}$ At the appropriate dosing frequencies, administration of adalimumab yields smooth and uniform time-concentration profiles due to the slow absorption rate from the SC tissue in combination with a slow elimination rate. ${ }^{14}$

Once adalimumab is administered $\mathrm{SC}$, absorption from the $\mathrm{SC}$ tissue to the circulation begins, at which point the drug then distributes to other tissue compartments, binding both soluble and cell-bound TNF- $\alpha .{ }^{14}$ It has been noted that binding part or all the TNF at various tissues may create concentration gradients, leading to TNF redistribution and alteration of drug pharmacokinetics. ${ }^{14}$ How much TNF is bound depends on the "on and off rate" of the drug for TNF, as well as molar concentrations, binding affinity, and the binding stoichiometry. ${ }^{4,14}$ Tissue penetration appears to be high, as the concentration of adalimumab in synovial fluid from patients with RA ranged from $31 \%$ to $96 \%$ of serum concentration. ${ }^{10}$

The concept of the "therapeutic window" for TNF antagonists suggests that since TNF is an important mediator of host defense against infectious organisms, abnormally low TNF levels in the body may lead to increased risk of opportunistic infections. ${ }^{15}$ It has been suggested that the therapeutic goal for TNF antagonists should not reduce levels below physiologic values that could compromise the individual's immunocompetency. ${ }^{15}$ Data from Granneman et $\mathrm{al}^{16}$ suggest that the steady-state serum concentration of adalimumab in typical doses (40 mg SC every other week) was about three to seven times greater than the necessary effective concentrations, which falls within the proposed therapeutic window. ${ }^{4,15}$

\section{Clinical efficacy Pediatric uveitis}

JIA is the most common form of identifiable uveitis in pediatric patients, accounting for $20 \%-40 \%$ of cases in most cohorts. ${ }^{17}$ JIA-associated uveitis is most commonly in the anterior chamber, is bilateral, presents insidiously without symptoms, and is chronic in the majority of cases. ${ }^{18}$ 
Ramanan et $\mathrm{al}^{19,20}$ presented data from the first randomized controlled trial of adalimumab in JIA-associated uveitis in abstract form in 2015. In this study, pediatric patients with active JIA-associated uveitis despite methotrexate use were randomly assigned to either placebo or adalimumab and followed for 2 years. The trial was stopped early for efficacy after 90 patients had been randomized, and the authors found the number of treatment failures were significantly reduced in the adalimumab group (hazard ratio $0.27,95 \%$ confidence interval [CI] 0.13-0.52). Publication of the trial is still pending, and the majority of additional data are limited to retrospective case series and observational studies. There is also heterogeneity in many of the published reports, as most include multiple disease processes and different outcome measures. Despite these limitations, Simonini et $\mathrm{a}^{21}$ published a 2012 systematic review and meta-analysis on anti-TNF therapy in childhood chronic uveitis, of which most patients had JIA, using the SUN Working Group grading scheme as the primary outcome measure. This study included five papers evaluating adalimumab $(\mathrm{n}=31)$ and found a pooled response rate of $87 \%$ ( $95 \%$ CI $75 \%-98 \%$ ) for improving intraocular inflammation. Additionally, 20 of 25 children were reported to obtain remission, and 22 of 31 were able to either taper or discontinue systemic corticosteroids. Table 2 provides a summary of additional selected studies evaluating adalimumab in pediatric uveitis.

One open-label, prospective trial for refractory noninfectious childhood uveitis compared the ability of adalimumab $\left(24 \mathrm{mg} / \mathrm{m}^{2}\right.$ every 2 weeks) and infliximab $(5 \mathrm{mg} / \mathrm{kg}$ at weeks 0,2 , and 6 , then every $6-8$ weeks thereafter, which is lower than is commonly used in the United States) to maintain remission. ${ }^{11}$ This study included 33 children: 22 with JIA, eight with idiopathic disease, two with Behçets, and one with sarcoidosis. In this study, there was no significant difference in time to achieve remission (15/16 children achieved disease remission in the first year with adalimumab) or discontinue corticosteroids; however, adalimumab had a higher probability of maintaining remission when compared to this low-dose infliximab. The National Italian Registry also evaluated the safety and efficacy of adalimumab and infliximab in 91 patients with refractory uveitis secondary to JIA and found that adalimumab had a higher remission rate $(67.4 \%$ vs $42.8 \%$ ); however, doses of infliximab were lower than those that are standardly used for treatment in the USA. ${ }^{22}$

Table 2 Adalimumab for pediatric uveitis

\begin{tabular}{|c|c|c|c|c|}
\hline Reference/study type & Patients & Primary outcome measure & Dosage of adalimumab & Result \\
\hline $\begin{array}{l}\text { Vazquez-Cobian et al' } \\
\text { prospective, open label }\end{array}$ & $\begin{array}{l}N=14 \text { total; age } 4-19 \text { years: } \\
\text { JIA }(n=9) \text {, idiopathic }(n=5)\end{array}$ & $\begin{array}{l}\text { Sustained improvement in AC } \\
\text { cell and/or flare over two visits } \\
3 \text { months apart }\end{array}$ & $\begin{array}{l}40 \mathrm{mg} / \mathrm{m}^{2} \text { every week } \\
\text { (if }<0.5 \mathrm{mg} / \mathrm{m}^{2}, 40 \mathrm{mg} \\
\text { every } 2 \text { weeks) }\end{array}$ & $\begin{array}{l}\text { Decreased AC flare in } 81 \% \\
(2 I / 26) \text { of affected eyes, all } \\
\text { patients able to taper at least one } \\
\text { other medication }\end{array}$ \\
\hline $\begin{array}{l}\text { Biester et al }{ }^{42} \\
\text { retrospective }\end{array}$ & $\begin{array}{l}N=18 \text { total; age of patients } \\
\text { with uveitis } 2-19 \text { years: JIA } \\
(n=17) \text {, idiopathic }(n=I)\end{array}$ & Relative relapse rate & $20-40 \mathrm{mg}$ every 2 weeks & $\begin{array}{l}88 \%(16 / 18) \text { effective, } 6 \% \text { mild } \\
\text { response, } 6 \% \text { no response }\end{array}$ \\
\hline $\begin{array}{l}\text { Bravo-Ljubetic et } \mathrm{a}^{43} \\
\text { retrospective }\end{array}$ & $\begin{array}{l}N=15 \text { total; age } 5-17 \text { years: } \\
\text { JIA }(n=10) \text {, idiopathic }(n=4) \text {, } \\
\text { Blau }(n=1)\end{array}$ & $\begin{array}{l}\text { I. SUN criteria for } \\
\text { improvement } \\
\text { 2. Effectiveness for recurrence } \\
\text { of uveitis: decrease in } \\
\text { frequency of acute attacks on } \\
\text { adalimumab vs prior therapy }\end{array}$ & $\begin{array}{l}\geq 30 \mathrm{~kg}, 40 \mathrm{mg} \text { every } \\
2 \text { weeks } \\
<30 \mathrm{~kg}, 20 \mathrm{mg} \text { every } \\
2 \text { weeks } \\
\text { Change to weekly at } \\
3 \text { months if not effective }\end{array}$ & $\begin{array}{l}\text { I. } 86 \% \text { of patients with improved } \\
\text { inflammation } \\
\text { 2. Effective in } 60 \%(9 / 15)(60 \% \\
\text { JIA), mildly in I3\%, ineffective in } \\
\text { I3\%, worsening in I3\% }\end{array}$ \\
\hline $\begin{array}{l}\text { Tynjala et al }{ }^{44} \\
\text { retrospective }\end{array}$ & 20 JIA; age 6-19 years & $\begin{array}{l}\text { I. SUN criteria (improved or } \\
\text { worsening) } \\
\text { 2. Mean number of flares/year }\end{array}$ & $\begin{array}{l}20 \text { or } 40 \mathrm{mg} \text { every } \\
2 \text { weeks (most also on } \\
\text { MTX, } 10-25 \mathrm{mg} / \mathrm{m}^{2} \\
\text { weekly) }\end{array}$ & $\begin{array}{l}\text { I. } 35 \%(7 / 20) \text { improved, } 5 \% \\
\text { worsened, } 60 \% \text { no change } \\
\text { 2. No significant change in mean } \\
\text { number of flares }\end{array}$ \\
\hline $\begin{array}{l}\text { Kotaniemi et } \mathrm{al}^{45} \\
\text { retrospective }\end{array}$ & $\begin{array}{l}\mathrm{N}=54 \text { total (uveitis); age } \\
3-15 \text { years (median): all JIA }\end{array}$ & $\begin{array}{l}\text { I. SUN criteria } \\
\text { 2. Clinical control (cells, flare, } \\
\text { or change in tCS) }\end{array}$ & $\begin{array}{l}24 \mathrm{mg} / \mathrm{m}^{2} \text { every } 2 \text { weeks: } \\
\text { increase up to weekly if } \\
\text { not responsive }\end{array}$ & $\begin{array}{l}\text { I. } 28 \% \text { (I5/54) improved, } 30 \% \\
\text { moderate response, } 30 \% \text { no } \\
\text { change, I } 3 \% \text { worsening } \\
\text { 2. } 31 \% \text { (I7/54) no tCS, } 35 \% \text { I-2 } \\
\text { tCS drops/day, } 33 \% \\
\geq 3 \mathrm{tCS} \text { drops/day }\end{array}$ \\
\hline $\begin{array}{l}\text { Sen et al }{ }^{46} \\
\text { prospective }\end{array}$ & $\begin{array}{l}N=17 \text { total; age } 5-20 \text { years: } \\
\text { JIA }(n=I 2) \text {, sarcoidosis } \\
(n=1) \text {, Blau }(n=2) \text {, } \\
\text { idiopathic }(n=2)\end{array}$ & $\begin{array}{l}\text { I. Visual acuity (logMar) } \\
\text { 2. SUN criteria (improved or } \\
\text { worsening) }\end{array}$ & $\begin{array}{l}20 \text { or } 40 \mathrm{mg} \text { every } \\
2 \text { weeks }\end{array}$ & $\begin{array}{l}\text { I. } 80 \% \text { eyes had improved vision } \\
\text { at } 3 \text { months } \\
\text { 2. } 50 \% \text { eyes had improved } \\
\text { inflammation at } 3 \text { months }\end{array}$ \\
\hline
\end{tabular}

Note: Paediatr Drugs, The future is now: biologics for non-infectious pediatric anterior uveitis, 17(4), 2015, 283-30I, Lerman MA, Rabinovich CE, ๑ Springer International Publishing Switzerland 2015, with permission of Springer. ${ }^{47}$

Abbreviations: JIA, juvenile idiopathic arthritis; SUN, Standardization of Uveitis Nomenclature; MTX, methotrexate; tCS, topical corticosteroid; AC, anterior chamber. 
As noted above, the collective weight of the evidence suggests that adalimumab is very effective in treating childhood noninfectious uveitis. Consistent with this, the American Academy of Ophthalmology (AAO) has recommended adalimumab be considered as a second-line agent after methotrexate for JIA-associated uveitis (good quality evidence). ${ }^{23}$

\section{Behçets}

Behçets classically causes a relapsing-remitting uveitis that can affect all parts of the uvea. Most patients present with bilateral disease, and inflammation of the entire uvea (panuveitis) is the most common manifestation of uveitis overall..$^{24}$

An expert panel from the AAO has made a strong recommendation in favor of treatment with anti-TNF therapy with infliximab or adalimumab (moderate quality evidence) as first- or second-line corticosteroid-sparing agents for patients with ophthalmic manifestations of Behçets. ${ }^{23}$ We briefly summarize a few key papers supporting this recommendation, as well as more recently published data.

In a 2010 literature review, adalimumab was documented in several case reports to show improvement in a total of 16/16 (100\%) patients with ocular involvement from Behçets. ${ }^{25}$ In a large multicenter retrospective study published in 2015, the French Behçets Network investigated the efficacy of anti-TNF agents for severe or refractory Behçets, including 47 patients having ocular manifestations treated with adalimumab. ${ }^{26}$ The authors found improvement with adalimumab in 23/24 (95.7\%) patients with uveitis, 3/4 (75\%) patients with macular edema, and $9 / 10(90 \%)$ patients with retinal vasculitis.

\section{Sarcoidosis}

Sarcoidosis is a multisystem inflammatory disease that can have ophthalmic involvement in $10 \%-80 \%$ of cases. $^{27}$ Although any part of the eye can be affected, uveitis is the most common manifestation, occurring in $20 \%-30 \%$ of patients with sarcoidosis. ${ }^{28}$ Of those with uveitis, the most common location is in the anterior chamber. ${ }^{29}$ Several studies have evaluated the efficacy of adalimumab for the treatment of uveitis in sarcoidosis. In one study, 26 patients with sarcoidosis and refractory posterior uveitis were followed for 12 months after initiation of adalimumab $40 \mathrm{mg}$ SC weekly. The authors found that intraocular inflammation improved in $22 / 26(85 \%)$ of patients, with choroidal involvement resolving in $10 / 15$, vasculitis resolving in $1 / 1$, papillitis resolving in $7 / 8$, and complete clearing of the vitreous in $5 / 5$ patients. ${ }^{30}$

Despite adalimumab showing very promising results for the treatment of sarcoid-related uveitis, some authors have reported that refractory uveitis in sarcoidosis is very unusual and advise clinicians to consider medication noncompliance, infection, or lymphoma as a cause for refractory disease. ${ }^{31}$

\section{Spondyloarthropathies}

The seronegative spondyloarthropathies (often associated with HLA-B27) are a heterogeneous group of inflammatory diseases that can involve the axial skeleton, the most common of which include psoriatic arthritis, inflammatory bowel disease, reactive arthritis, and ankylosing spondylitis. Due to this heterogeneity, the prevalence of uveitis varies by condition. According to one systematic review, the prevalence of uveitis can range from $13 \%$ with undifferentiated disease to $33 \%$ with ankylosing spondylitis. ${ }^{32}$ It is worth noting, however, that other estimates of prevalence differ significantly. ${ }^{33}$ Unlike many other forms of uveitis, the spondyloarthropathies classically cause an acute symptomatic uveitis involving the anterior chamber. ${ }^{33}$ Unfortunately, the recurrence of uveitis is frequently encountered in clinical practice, and rarely, the uveitis can take a more chronic form. ${ }^{23}$

Due to the heterogeneity of this category, we will briefly summarize evidence regarding adalimumab for treatment of uveitis in ankylosing spondylitis, as this is generally felt to have the highest prevalence of uveitis as already noted. A subanalysis of a previously published multinational, open-label clinical trial evaluated adalimumab for the treatment of uveitis in 1,250 patients with active ankylosing spondylitis and found that treatment decreased the overall flare rate by $51 \%{ }^{34}$

The AAO has strongly recommended that infliximab or adalimumab may be used as a corticosteroid-sparing agent for chronic uveitis resulting from seronegative spondyloarthropathies. The AAO has also made a discretionary recommendation using these same agents for severe, visionthreatening disease, or as an adjunct to corticosteroid treatment in acute disease. ${ }^{23}$

\section{Other refractory uveitis}

Adalimumab has also shown to be especially promising in cases of refractory uveitis in studies with a very heterogeneous population. A large prospective case series in Spain reported the use of adalimumab in 131 patients with refractory uveitis including both adult and pediatric patients (most with JIA, idiopathic uveitis, pars planitis, and Behçets). In this study, adalimumab was, overall, shown to decrease anterior chamber and vitreous inflammation, macular thickness, and reduce corticosteroid use. ${ }^{35}$ Another prospective, multicenter trial evaluated the use adalimumab for refractory uveitis in 31 adult patients and found a clinical response in $68 \%$ 
of patients at 10 weeks (defined as well-controlled ocular inflammation and improvement in at least one other parameter with no worsening in any parameters); of these, 39\% had continued response after 50 weeks. ${ }^{36}$ Additionally, investigators for the Systemic Immunosuppressive Therapy for Eye Diseases research group evaluated the use of adalimumab for 32 patients with various ocular inflammatory diseases, most with "stubborn or recalcitrant" anterior uveitis or scleritis, and found that inflammation went from "active" to "inactive" in seven of 15 eyes (47\%) at 6 months. ${ }^{37}$

\section{Safety}

At the time of this writing, TNF inhibitors currently have black box warnings for serious infections (including but not limited to mycobacterial and invasive fungal infections) and malignancy, including lymphoma in children and adolescents and postmarketing cases of hepatosplenic T-cell lymphoma. The initial concern for malignancy was based largely on a review of the FDA's Adverse Event Reporting System in 2009, at which time 48 cases of malignancy were reported in children and adolescents, most of whom had inflammatory bowel disease. ${ }^{38} \mathrm{~A}$ causal relationship is very difficult to establish, however, as all but six patients were concomitantly taking other immune-suppressing medications (most commonly azathioprine or 6-mercaptopurine). Subsequent studies in adults have not confirmed an increased risk of malignancy in patients treated with TNF inhibitors, with the exception of nonmelanoma skin cancers. ${ }^{39}$ For example, a 2011 systematic review and meta-analysis of TNF inhibitors in RA found no increased risk of lymphoma with the use of TNF inhibitors. ${ }^{40}$

The safety of adalimumab is also well informed by data from large registries. Data from the National Italian Registry evaluated the safety of adalimumab in 43 patients with JIAassociated uveitis over a 3-year period and found there were no major adverse events and only two minor adverse events (one rash and one prolonged menses), though others point out this frequency was less than observed in other studies. ${ }^{22}$ In the German JIA registry, 48 of 289 patients experienced a total of 222 adverse events, only 11 of which were defined as serious (2.5 per 100 patient-years). There were no deaths, malignancies, opportunistic infections, demyelinating disease, or lupus-like reactions. ${ }^{41}$

\section{Conclusion}

Adalimumab and other biologic agents have revolutionized the treatment for noninfectious uveitis. In this paper, we present pharmacologic data regarding the TNF- $\alpha$ inhibitor adalimumab, as well as the role of TNF- $\alpha$ in uveitis. Adalimumab has shown efficacy in treating refractory uveitis in multiple settings, including idiopathic disease, JIA, sarcoidosis, Behçets, and uveitis secondary to spondyloarthropathies, among several other noninfectious uveitis conditions. In our experience, the side effect profile and safety of adalimumab is felt to be, overall, quite acceptable in clinical practice. Although the precise timing of initiation of biologic agents for uveitis is an area of ongoing investigation, these agents are increasingly being used due to their efficacy and corticosteroid-sparing effect, which can reduce treatmentrelated ocular adverse events and improve outcomes.

\section{Disclosure}

C Egla Rabinovich: Research grants from Janssen Research \& Development, L.L.C.; UCB Pharma, Inc.; Hoffmann-La Roche, Inc.; and AbbVie, Inc. The authors report no other conflicts of interest in this work.

\section{References}

1. Dunn JP. Uveitis. Prim Care. 2015;42(3):305-323.

2. Jabs DA, Nussenblatt RB, Rosenbaum JT; Standardization of Uveitis Nomenclature Working Group. Standardization of uveitis nomenclature for reporting clinical data. Results of the First International Workshop. Am J Ophthalmol. 2005;140(3):509-516.

3. Pasadhika S, Rosenbaum JT. Update on the use of systemic biologic agents in the treatment of noninfectious uveitis. Biologics. 2014;8: 67-81.

4. Tracey D, Klareskog L, Sasso EH, Salfeld JG, Tak PP. Tumor necrosis factor antagonist mechanisms of action: a comprehensive review. Pharmacol Ther. 2008;117(2):244-279.

5. Neri P, Zucchi M, Allegri P, Lettieri M, Mariotti C, Giovannini A. Adalimumab (Humira): a promising monoclonal anti-tumor necrosis factor alpha in ophthalmology. Int Ophthalmol. 2011;31(2):165-173.

6. Feldmann M. Development of anti-TNF therapy for rheumatoid arthritis. Nat Rev Immunol. 2002;2(5):364-371.

7. Dick AD. Immune mechanisms of uveitis: insights into disease pathogenesis and treatment. Int Ophthalmol Clin. 2000;40(2):1-18.

8. Curnow SJ, Falciani F, Durrani OM, et al. Multiplex bead immunoassay analysis of aqueous humor reveals distinct cytokine profiles in uveitis. Invest Ophthalmol Vis Sci. 2005;46(11):4251-4259.

9. Mo JS, Matsukawa A, Ohkawara S, Yoshinaga M. Involvement of TNF alpha, IL-1 beta and IL-1 receptor antagonist in LPS-induced rabbit uveitis. Exp Eye Res. 1998;66(5):547-557.

10. Humira ${ }^{\circledR}$ (adalimumab) [prescribing information]. Illinois: AbbVie, Inc; 2016.

11. Simonini G, Taddio A, Cattalini M, et al. Prevention of flare recurrences in childhood-refractory chronic uveitis: an open-label comparative study of adalimumab versus infliximab. Arthritis Care Res (Hoboken). 2011; 63(4):612-618.

12. Vazquez-Cobian LB, Flynn T, Lehman TJ. Adalimumab therapy for childhood uveitis. J Pediatr. 2006;149(4):572-575.

13. Hamam RN, Barikian AW, Antonios RS, et al. Intravitreal adalimumab in active noninfectious uveitis: a pilot study. Ocul Immunol Inflamm. 2016;24(3):319-326.

14. Nestorov I. Clinical pharmacokinetics of tumor necrosis factor antagonists. J Rheumatol Suppl. 2005;74:13-18.

15. Nestorov I. Clinical pharmacokinetics of TNF antagonists: how do they differ? Semin Arthritis Rheum. 2005;34(5 Suppl 1):12-18. 
16. Granneman RG, Zhang Y, Noertersheuser PA, Velagapudi RB, Awni WM, Locke CS. Pharmacokinetic/Pharmacodynamic (PK/PD) Relationships of Adalimumab (HUMIRA ${ }^{\mathrm{TM}}$ ) in Rheumatoid Arthritis (RA) Patients During Phase II/III Clinical Trials (Poster 2562003) Poster presented at: ACR Annual Scientific Meeting; October 24-28; 2003; Orlando, FL.

17. Rabinovich CE. Use of tumor necrosis factor inhibitors in uveitis. Curr Opin Rheumatol. 2007;19(5):482-486.

18. Heinz C, Mingels A, Goebel C, Fuchsluger T, Heiligenhaus A. Chronic uveitis in children with and without juvenile idiopathic arthritis: differences in patient characteristics and clinical course. J Rheumatol. 2008; 35(7):1403-1407.

19. Ramanan AV, Dick AD, Benton D, et al. A randomised controlled trial of the clinical effectiveness, safety and cost-effectiveness of adalimumab in combination with methotrexate for the treatment of juvenile idiopathic arthritis associated uveitis (SYCAMORE Trial). Trials. 2014;15:14

20. Ramanan AV, Dick AD, McKay A, et al. A randomised controlled trial of the clinical effectiveness, safety and cost-effectiveness of adalimumab in combination with methotrexate for the treatment of juvenile idiopathic arthritis associated uveitis [abstract]. Arthritis Rheumatol. 2015;67(Suppl 10).

21. Simonini G, Druce K, Cimaz R, Macfarlane GJ, Jones GT. Current evidence of anti-tumor necrosis factor alpha treatment efficacy in childhood chronic uveitis: a systematic review and meta-analysis approach of individual drugs. Arthritis Care Res (Hoboken). 2014;66(7): 1073-1084.

22. Zannin ME, Birolo C, Gerloni VM, et al. Safety and efficacy of infliximab and adalimumab for refractory uveitis in juvenile idiopathic arthritis: 1-year follow up data from the Italian Registry. $J$ Rheumatol. 2013;40(1):74-79.

23. Levy-Clarke G, Jabs DA, Read RW, Rosenbaum JT, Vitale A, Van Gelder RN. Expert panel recommendations for the use of anti-tumor necrosis factor biologic agents in patients with ocular inflammatory disorders. Ophthalmology. 2014;121(3):785-796.e3.

24. Tugal-Tutkun I, Onal S, Altan-Yaycioglu R, Huseyin Altunbas H, Urgancioglu M. Uveitis in Behcet disease: an analysis of 880 patients. Am J Ophthalmol. 2004;138(3):373-380.

25. Arida A, Fragiadaki K, Giavri E, Sfikakis PP. Anti-TNF agents for Behcet's disease: analysis of published data on 369 patients. Semin Arthritis Rheum. 2011;41(1):61-70.

26. Vallet H, Riviere S, Sanna A, et al. Efficacy of anti-TNF alpha in severe and/or refractory Behcet's disease: multicenter study of 124 patients. J Autoimmun. 2015;62:67-74.

27. Riancho-Zarrabeitia L, Calvo-Rio V, Blanco R, et al. Anti-TNF-alpha therapy in refractory uveitis associated with sarcoidosis: multicenter study of 17 patients. Semin Arthritis Rheum. 2015;45(3):361-368.

28. Bodaghi B, Touitou V, Fardeau C, Chapelon C, LeHoang P. Ocular sarcoidosis. Presse Med. 2012;41(6 Pt 2):e349-e354.

29. Lee SY, Lee HG, Kim DS, Kim JG, Chung H, Yoon YH. Ocular sarcoidosis in a Korean population. J Korean Med Sci. 2009;24(3):413-419.

30. Erckens RJ, Mostard RL, Wijnen PA, Schouten JS, Drent M. Adalimumab successful in sarcoidosis patients with refractory chronic noninfectious uveitis. Graefes Arch Clin Exp Ophthalmol. 2012;250(5): 713-720.
31. Jamilloux Y, Kodjikian L, Broussolle C, Seve P. Sarcoidosis and uveitis. Autoimmun Rev. 2014;13(8):840-849.

32. Zeboulon N, Dougados M, Gossec L. Prevalence and characteristics of uveitis in the spondyloarthropathies: a systematic literature review. Ann Rheum Dis. 2008;67(7):955-959.

33. Rosenbaum JT. Uveitis in spondyloarthritis including psoriatic arthritis, ankylosing spondylitis, and inflammatory bowel disease. Clin Rheumatol. 2015;34(6):999-1002.

34. Rudwaleit M, Rodevand E, Holck P, et al. Adalimumab effectively reduces the rate of anterior uveitis flares in patients with active ankylosing spondylitis: results of a prospective open-label study. Ann Rheum Dis. 2009;68(5):696-701.

35. Diaz-Llopis M, Salom D, Garcia-de-Vicuna C, et al. Treatment of refractory uveitis with adalimumab: a prospective multicenter study of 131 patients. Ophthalmology. 2012;119(8):1575-1581.

36. Suhler EB, Lowder CY, Goldstein DA, et al. Adalimumab therapy for refractory uveitis: results of a multicentre, open-label, prospective trial. Br J Ophthalmol. 2013;97(4):481-486.

37. Durrani K, Kempen JH, Ying GS, et al. Adalimumab for ocular inflammation. Ocul Immunol Inflamm. 2016:1-8.

38. Diak P, Siegel J, La Grenade L, Choi L, Lemery S, McMahon A. Tumor necrosis factor alpha blockers and malignancy in children: forty-eight cases reported to the Food and Drug Administration. Arthritis Rheum. 2010;62(8):2517-2524.

39. Park HJ, Ranganathan P. TNF-alpha antagonism and cancer risk in rheumatoid arthritis: is continued vigilance warranted? Discov Med. 2012;13(70):229-234.

40. Mariette X, Matucci-Cerinic M, Pavelka K, et al. Malignancies associated with tumour necrosis factor inhibitors in registries and prospective observational studies: a systematic review and meta-analysis. Ann Rheum Dis. 2011;70(11):1895-1904.

41. Schmeling H, Minden K, Foeldvari I, Ganser G, Hospach T, Horneff G. Efficacy and safety of adalimumab as the first and second biologic agent in juvenile idiopathic arthritis: the German Biologics JIA Registry. Arthritis Rheumatol. 2014;66(9):2580-2589.

42. Biester S, Deuter C, Michels H, et al. Adalimumab in the therapy of uveitis in childhood. Br J Ophthalmol. 2007;91(3):319-324.

43. Bravo-Ljubetic L, Peralta-Calvo J, Noval S, Pastora-Salvador N, Abelairas-Gomez J, Merino R. Adalimumab therapy for refractory childhood uveitis. J AAPOS. 2013;17(5):456-459.

44. Tynjala P, Kotaniemi K, Lindahl P, et al. Adalimumab in juvenile idiopathic arthritis-associated chronic anterior uveitis. Rheumatology (Oxford). 2008;47(3):339-344.

45. Kotaniemi K, Saila H, Kautiainen H. Long-term efficacy of adalimumab in the treatment of uveitis associated with juvenile idiopathic arthritis. Clin Ophthalmol. 2011;5:1425-1429.

46. Sen ES, Sharma S, Hinchcliffe A, Dick AD, Ramanan AV. Use of adalimumab in refractory non-infectious childhood chronic uveitis: efficacy in ocular disease - a case cohort interventional study. Rheumatology (Oxford). 2012;51(12):2199-2203.

47. Lerman MA, Rabinovich CE. The future is now: biologics for non-infectious pediatric anterior uveitis. Paediatr Drugs. 2015;17(4) 283-301.

\section{Publish your work in this journal}

Drug Design, Development and Therapy is an international, peerreviewed open-access journal that spans the spectrum of drug design and development through to clinical applications. Clinical outcomes, patient safety, and programs for the development and effective, safe, and sustained use of medicines are the features of the journal, which

\section{Dovepress}

has also been accepted for indexing on PubMed Central. The manuscript management system is completely online and includes a very quick and fair peer-review system, which is all easy to use. Visit http://www.dovepress.com/testimonials.php to read real quotes from published authors. 